\title{
Estudo da Correlação entre o Estadiamento Clínico e as Alterações Esqueléticas das Metástases Ósseas do Câncer da Mama
}

\author{
Correlation Between Clinical Staging and Skeletal Alterations of Bone
}

Metastases in Breast Cancer Patients

Helton L.A. Defino ${ }^{1}$, Flávio L.Garcia², Leonardo C. Simionato ${ }^{3}$, Angelo C. S. Matthes ${ }^{4}$, Séglo Bighetti ${ }^{5}$

\section{RESUMO}

Foram estudadas 48 pacientes com câncer da mama e que apresentavam metástases ósseas, com o objetivo de avaliar-se a correlação entre o estadiamento clínico do tumor primário, de acordo com protocolo do Comitê Americano de Estadiamento do Câncer, e as manifestações esqueléticas das metástases ósseas, tendo sido utilizados como parâmetros para essa avaliação o período de seguimento, o número de metástases, o tipo de lesão, a sua localização e a região do osso acometida.

Foi observado correlação entre o estadiamento da lesão primária e o tempo de seguimento, que diminuia à medida que o grau de estadiamento aumentava, não tendo sido observado correlação entre o estadiamento clínico do câncer de mama e os demais parâmetros estudados.

Unitermos: Metástase óssea; Câncer de mama.

\section{SUMMARY}

Forty-eight breast cancer patients with bone metastases were studied aiming to evaluate the correlation between clinical staging of the primary tumor, according to the Cancer Staging American Committee protocol, and the skeletal manifestations of the bone metastases; the assessment parameters were the follow-up period, the number of metastases, the type of the lesions, their localization, and the affected bone region.

A correlation was found between the primary lesion staging and the follow-up period, which was reduced when the staging degree increased; no correlation was observed between breast cancer clinical staging and the other parameters.

Key-words: Bone metastasis; breast cancer

1 Professor Associado do Departamento de Cirurgia, Ortopedia e Traumatologia da FMRP- USP 


\section{INTRODUÇÃO}

As neoplasias são oriundas de distúrbios da regulação do crescimento das células, que resulta na sua proliferação anormal associada a lesões locais. As células neoplásicas possuem a capacidade de invadir os tecidos vizinhos, e também de destacar-se de seu local de origem, proliferando em tecidos e locais distantes do sítio primário, que são denominadas de metástases. ${ }^{(16)}$

A susceptibilidade dos diferentes tecidos às metástases tumorais permanece ainda sem explicação, e observamos tecidos que apresentam alta porcentagem de metástases tumorais e raramente são acometidos por tumores primários, como ocorre com o tecido ósseo, contrastando com a mama e o cólon , que apresentam alta incidência de lesões tumorais primárias e raras lesões metastáticas. No pulmão observamos ainda padrão distinto, com alta incidência de lesões tumorais primárias e também de metástases. ${ }^{(16)}$

Os estudos de autópsia tem demonstrado que as metástases ósseas são particularmente frequentes nos pacientes que evoluem para o óbito devido a neoplasia da mama, brônquios, próstata, rins e tireóide ${ }^{(5,6)}$ e provavelmente os tumores da mama, brônquios e próstata são responsáveis por cerca de $80 \%$ das metástases do tecido ósseo. ${ }^{(7)}$

O carcinoma da mama é o tumor de maior prevalência nas mulheres da Europa Ocidental e América do Norte, existindo no Reino Unido cerca de 24000 casos novos por ano, que são responsáveis por 15000 mortes anuais. ${ }^{(16)} O$ carcinoma da mama éa neoplasia que apresenta a maior frequência de metástases ósseas, cujos relatos variam de 38,6 a 49,6\% ${ }^{(8,12,15)}$, e esse fato, associado ao crescente número de pacientes que tem recebido tratamento ortopédico devido às metástases de carcinoma da mama, motivou a realização desse trabalho, que teve como principal objetivo a observação da possível correlação entre as características clínicas e radiológicas das lesões ósseas metastáticas com o estadiamento da lesão primária da mama , e a influência que o estadiamento da lesão primária da mama poderia apresentar na elaboração da abordagem diagnóstica ou terapêutica das lesões ósseas.

\section{MATERIAL E MÉTODOS}

Foram estudadas retrospectivamente 48 pacientes do sexo feminino com idade que variou de 36 à 72 anos (média de 53 anos), atendidas no período de março de 1990 à fevereiro de 1997 pela Área de Ginecologia e Obstetrícia , e Área de Ortopedia e Traumatologia da Faculdade de Medicina de Ribeirão Preto- USP, que apresentavam carcinoma de mama com metástase óssea.

O estadiamento clínico das pacientes foi realizado de acordo com o protocolo do Comitê Americano de Estadiamento do Câncer(Tabela I), sendo que 7(14,5\%) pacientes enquadravam-se no estadio I, 14(29,1\%) no estadio II, 18(37,5\%) no estadio III, e $9(18,7 \%)$ no estadio IV. Tabelas II, III, IV, V e VI.

O tipo histológico do tumor primário era ductal infiltrante em 44 pacientes $(91,6 \%)$, lobular infiltrante em $2(4,2 \%)$, medular em 1 $(2,1 \%)$ e papilífero em $1(2,1 \%)$. Quinze pacientes apresentavam

\section{INTRODUCTION}

The neoplasias are consequence of cell growth regulation disorders, resulting in abnormal proliferation associated to local lesions. The neoplastic cells spread on the surrounding tissues, and also detach from their original site, proliferating in tissues and locals distant from the primary site, forming metastases. 16

The susceptibility of different tissues to tumor metastases has still to be explained, and there are tissues, as the bone, with a high percentage of tumor metastases but rarely affected by primary tumors, in contrast with breast and colon which present high incidence of primary lesions and scarce metastatic lesions. The lungs evidence a distinct pattern, with high incidence of primary tumor lesions and also metastases. 16

Autopsies have shown that bone metastases are particularly frequent in patients which die due to breast, bronchi, prostate, kidney and thyroid neoplasms 5,6 and probably the breast, bronchi and prostate tumors are responsible for about $80 \%$ of the bone metastases. 7

Breast carcinoma is the most prevalent tumor in West European and North American women; in the United Kingdom, about 24000 new yearly cases are detected, responsible for 15000 annual deaths. 16 The breast carcinoma presents the highest frequency of bone metastases, reported as 38.6 to $49.6 \%(8,12,15)$ and this observation associated to the growing number of patients receiving orthopedic treatment due to breast carcinoma metastases led to this investigation, whose main objective was to determine a possible correlation between the clinical and radiological characteristics of the metastatic bone lesions with the staging of the breast primary lesion, and the influence of this staging on the elaboration of diagnostic or therapeutic approaches for bone lesions.

\section{MATERIAL AND METHOD}

Forty-eight 36 to 72 year-old (mean 53 years) female patients were retrospectively studied. They were attended from March, 1990 to February, 1997 in the Ginecology and Obstetrics and Orthopedics and Traumatology Areas of the Ribeirão Preto College of Medicine, University of São Paulo (FMRP-USP), presenting breast carcinoma with bone metastases.

Clinical staging was effected according to the Cancer Staging American Committee protocol (Table I), and 7 (14.5\%) patients were Stage I, 14 (29.1\%) stage II, 18 (37.5\%) stage III and 9 (18.7\%) stage N. Tables II, III, IV, V and VI.

The histological types of the primary tumor were: ductal infiltrative, 44 patients (91.6\%), lobular infiltrative, 2 (4.2\%), medullary, 1 (2.1\%), and papilliferous, 1 (2.1\%). Fifteen patients had only one metastasis (31.2\%), and 33 (68.8\%) had multiple metastases (Fig. 1). The metastases were lithic, 35 patients (72.9\%), blastic, 2 patients (4.2\%), and mixed in 11 patients (22.9\%) (Fig. 2). The most affected bones were the ribs, 22 patients (45.8\%), the spinal column, 20 (41.6\%) 
metástase única $(31,2 \%)$ e 33 (68,8\%) metástases múltiplas (Fig. 1). As metástases eram do tipo lítico em 35 pacientes (72,9\%), blásticas em 2 (4,2\%) e mistas em 11 pacientes (22,9\%) (Fig. 2). Os ossos mais acometidos foram as costelas em 22 pacientes (45,8\%), coluna vertebral em 20 (41,6\%) e fêmur em 18 (37,5\%). A distribuição da localização óssea das metástases está ilustrada na Tabela II, e observou-se que nos ossos longos longos 6 lesões (20\%) eram diafisárias, 20 (66,7\%) metafisárias e 4 (13,3\%) epifisárias.

$\mathrm{Na}$ coluna vertebral 9 pacientes apresentavam lesão ao nível da coluna torácica (45\%), 9 ao nível da coluna lombar (45\%), 1 na coluna sacral (5\%) e 1 na coluna cervical (5\%). O corpo vertebral estava acometido em 14 pacientes (70\%), o pedículo em 5 (25\%) e os elementos posteriores da vértebra em 1 paciente $(5 \%)$. and the femur, 18 (37.5\%). The bone localization of the metastases is in Table II; in the long bones 6 lesions were diaphyseal (20\%), 20 (66.7\%) metaphyseal and 4 (13.3\%) epiphyseal.

In the spinal column, 9 patients (45\%) had lesions at the thoracic, $9(45 \%)$ at the lumbar, 1 (5\%) at the sacral, and 1 (5\%) at the cervical levels. The vertebral body was affected in 14 patients (70\%), the pedicle in 5 (25\%) and the posterior elements in 1 patient (5\%).

Tabela I - Estadiamento clínico do carcinoma mamário, segundo o protocolo do Comitê Americano de Estadiamento do Câncer

Table I - Clinical staging of breast cancer according to the the Cancer Staging American Committee protocol.

A presença de lesões ósseas foi avaliada em todas as pacientes por meio de cintilografia óssea com tecnécio 99 e radiografias simples, tendo sido utilizado em 4 pacientes, estudo complementar com tomografia computadorizada para a confirmação da lesão óssea.

Os parâmetros considerados na avaliação das lesões ósseas metastáticas foram: o número de metástases ósseas (única ou múltipla), o tipo da lesão (lítica, blástica ou mista), a sua localização e a região do osso acometida, tendo sido esses parâmetros avaliados e comparados nos 4 grupos de pacientes, formados de acordo com o seu enquadramento no estadio clínico da lesão primária (Protocolo do Comitê Americano de Estadiamento do Câncer).

\section{Tabela II - Características clínicas e radiológicas das pacientes estudadas (estadios I, II, III, IV)} Número de Pacientes - 48
The presence ofbonelesions was detected by means of bone scintillography with technetium 99 and $X$-rays, and in 4 patients a complementary study with computerized tomography was carried out to confirm the bone lesion.

The parameters considered to evaluate the metastatic bone lesions were: number of bone metastases (single or multiple), type of lesion (lithic, blastic or mixed), localization and region involved; the parameters were evaluated and compared in 4 groups of patients, allocated according to their categorization in the primary lesion clinical staging (Cancer Staging American Committee Protocol).

\begin{tabular}{|c|c|}
\hline \multicolumn{2}{|c|}{ Tipo Histológico } \\
\hline ductal infiltrante & $44(91,6 \%)$ \\
\hline lobular infiltrante & $2(4,2 \%)$ \\
\hline medular & $1(2,1 \%)$ \\
\hline papilifero & $2(2,1 \%)$ \\
\hline \multicolumn{2}{|c|}{ Tipo da Lesăo Óssea } \\
\hline Litica & $35(72,9 \%)$ \\
\hline Blástica & $2(4,2 \%)$ \\
\hline Ambas & $11(22,9 \%)$ \\
\hline \multicolumn{2}{|c|}{ Localizaçăo Ossos Longos } \\
\hline Diáfise & $6(20 \%)$ \\
\hline Metáfise & $20(66,7 \%)$ \\
\hline Epifise & $4(13,3 \%)$ \\
\hline
\end{tabular}

Table II - Clinical and radiological characteristics of the patients (stages I, II, III, IV) Number of Patients - 48 
Tabela III - Características clínicas e radiológicas das pacientes pertencentes ao estadio I Número de Pacientes - 7
Table III - Clinical and radiological characteristics of stage I patients Number of Patients - 7
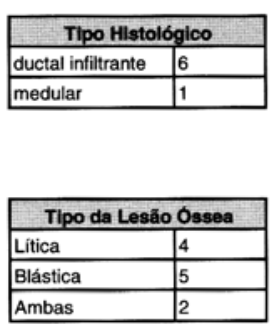

\begin{tabular}{|l|r|}
\hline \multicolumn{2}{|c|}{ Local. Ossos Longos } \\
\hline Diáfise & 1 \\
\hline Metáfise & 2 \\
\hline Epífise & 1 \\
\hline
\end{tabular}

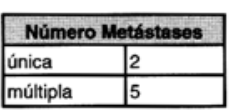

\begin{tabular}{|l|l|}
\hline \multicolumn{2}{|c|}{ Osso Acometido } \\
\hline Ûmero & 3 \\
\hline Costela & 3 \\
\hline Fêmur & 2 \\
\hline Bacia & 2 \\
\hline Esterno & 2 \\
\hline Escápula & 1 \\
\hline
\end{tabular}

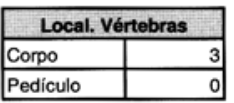

Tempo Médio de Seguimento: 6 anos e 4 meses Idade Média: 60 anos

Tabela IV - Características clínicas e radiológicas das pacientes pertencentes com estadio III

Número de Pacientes - 18
Table IV - Clinical and radiological characteristics of stage III patients Number of patients 18
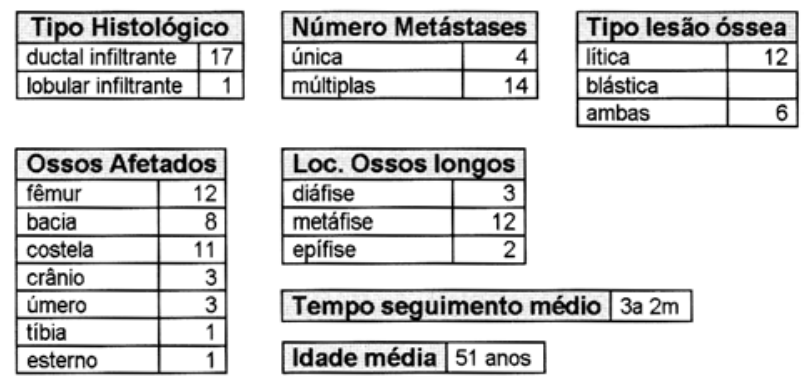

\begin{tabular}{|l|l|}
\hline Tempo seguimento médio & $3 \mathrm{a} 2 \mathrm{~m}$ \\
\hline
\end{tabular}

\begin{tabular}{|l|l|}
\hline Idade média & 51 anos \\
\hline
\end{tabular}

Tempo médio de seguimento -3 anos e 2 meses

Idade média -60 anos

Tabela V - Características clínicas e radiológicas das pacientes pertencentes ao estadio III

Número de Pacientes 18
Table V - Clinical and radiological characteristics of stage III patients

Number of patients 18

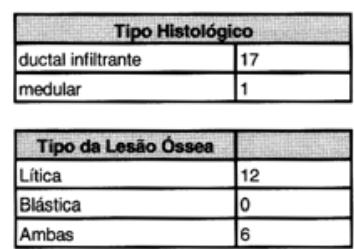

Ambas

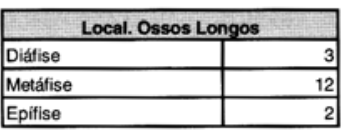

Tempo Médio de Seguimento: 3 anos e 2 meses Idade Média: 51 anos
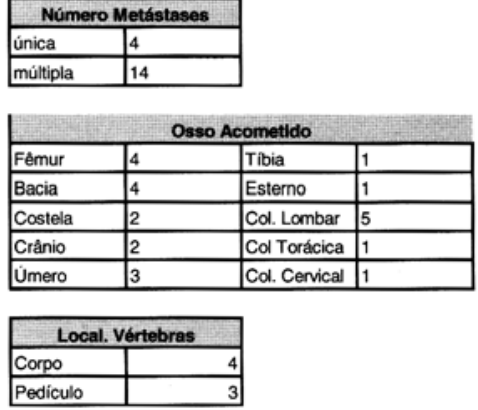
Tabela VI - Características clínicas e radiológicas das pacientes pertencentes ao Estadio IV Número de Pacientes 9

\section{Table VI - Clinical and radiological characteristics of the Stage IV patients \\ Number of Patients 9}

\begin{tabular}{|l|l|}
\hline \multicolumn{2}{|c|}{ Tipo Histológico } \\
\hline ductal infiltrante & 8 \\
\hline medular & 1 \\
\hline
\end{tabular}

\begin{tabular}{|l|l|}
\hline \multicolumn{1}{|c|}{ Tipo da Lesão Ossea } & \\
\hline Lítica & 6 \\
\hline Blástica & 11 \\
\hline Ambas & 2 \\
\hline
\end{tabular}

\begin{tabular}{|l|r|}
\hline Local. Ossos Longos & \\
\hline Diáfise & 1 \\
\hline Metáfise & 5 \\
\hline Epífise & 1 \\
\hline
\end{tabular}

Tempo Médio de Seguimento: 1 ano 3 meses Idade Média: 57 anos

\begin{tabular}{|l|l|}
\hline \multicolumn{2}{|c|}{ Número Metástases } \\
\hline única & 3 \\
\hline múltipla & 6 \\
\hline
\end{tabular}

\begin{tabular}{|l|l|}
\hline \multicolumn{2}{|c|}{ Osso Acometido } \\
\hline Bacia & 4 \\
\hline Crânio & 4 \\
\hline Costela & 2 \\
\hline Úmero & 2 \\
\hline Fêmur & 3 \\
\hline Escápula & 2 \\
\hline Tíbia & 1 \\
\hline Rádio & 1 \\
\hline
\end{tabular}

\begin{tabular}{|l|r|}
\hline \multicolumn{2}{|c|}{ Local. Vértebras } \\
\hline Corpo & 3 \\
\hline Pediculo & 2 \\
\hline
\end{tabular}

\section{RESULTADOS}

A média do período de seguimento dos pacientes estudados foi de 3 anos e 6 meses, e foi observado que no grupo de pacientes com estadio I a média foi de 6 anos e 4 meses, no estadio II 3 anos e 10 meses, no estadio III 3 anos e 2 meses, e no estadio IV 1 ano e 3 meses. (Fig. 3)

O carcinoma tipo ductal infiltrante foi o tipo histológico que predominou no grupo de pacientes estudados $(91,6 \%)$, tendo sido também observado a sua predominância nos diferentes estadios clínicos ( estadio I-85,7\% ; estadio II-92,8\% ; estadio III - 94,4\% e estadio IV $-88,8 \%)$.

As metástases múltiplas predominaram no grupo de pacientes estudados, tendo sido observadas em $68,8 \%$ dos pacientes. As metástase múltiplas também foram as mais frequentes nos diferentes estadios clínicos , tendo sido observada em $71,4 \%$ dos pacientes com estadio I; $57,1 \%$ dos pacientes com estadio II ; $77,7 \%$ com estadio III e 75\% com estadio IV. (Fig. 1)

A costela foi o osso mais acometido pelas metástases (45,8\%), seguida pela coluna vertebral $(41,6 \%$ ) e fêmur (37,5\%). A distribuição das metástases na coluna vertebral apresentou predileção pelo seu segmento torácico e lombar. A localização das metástases está

\section{RESULTS}

The mean follow-up period of the studied patients was 3 years and 6 months; in the stage I patients the mean was 6 years and 4 months; in stage II, 3 years and 10 months; in stage III 3 years and 2 months; and in stage IV, 1 year and 3 months. (Fig. 3).

The infiltrative ductal carcinoma was the histological type which predominated (91.6\%), and its predominance was also observed in the different clinical stages (stage I - 85.7\%; stage II - 92.8\%; stage III - 94.4\% and stage $N-88.8 \%)$.

The multiple metastases predominated in the group of study, and they were observed in $68.8 \%$ of the patients. The multiple metastases were also the most frequent in the different clinical stages; they were observed in $71.4 \%$ of the patients stage I; $57.1 \%$ of the patients stage $1 /$; $77.7 \%$ stage III; and $75 \%$ stage N. (Fig. 1)

The rib was the most involved bone $(45.8 \%)$, followed by the spinal column (41.6\%) and femur (37.5\%). The distribution of the metastases in the spinal column prevailed in the thoracic and lumbar segments. The metastases localization is presented in Tables III, IV, V and VI and no differences were observed between the clinical stages, the most frequent localization being the ribs 
representada na Tabela III, IV,V e VI, e não foi observado diferença entre os diferentes estadios clínicos, tendo sido observado a localização mais frequente nas costelas e coluna vertebral em todos os estádios, com exceção do estadio III no qual foi observado metástase femoral com maior frequência.

A localização óssea mais frequente das metástases foi a região metafisária dos ossos longos (66,7\%) e corpo vertebral (70\%), não tendo sido observado diferenças entre os diferentes estadios clínicos.

O tipo de lesão (lítica ou blástica) também não apresentou correlação com os diferentes estadios clínicos do tumor primário, apresentando distribuição variável nos diferentes estadios. (Fig. 2)

A análise dos parâmetros estudados mostrou haver correlação entre o estadiamento clínico do tumor primário e o período de seguimento, que diminuia à medida que o grau de estadiamento clínico aumentava, não tendo sido observado nenhuma correlação entre os demais parâmetros estudados (tipo histológico, número de metástases, tipo de lesão, osso acometido e localização óssea) e o estadiamento clínico dos tumores da mama. and spinal column in all stages, with the exception of stage III where femoral metastases were more frequently observed.

The most frequent bone localization of the metastases was the long bones metaphyseal region (66.7\%) and the vertebral body (70\%); no differences were observed between the different clinical stages.

The kind of lesion (lithic or blastic) also had no correlation with the different clinical stages of the primary tumor, presenting a variable distribution in the different stages (Fig. 2).

The analysis of the parameters showed correlation between the clinical staging of the primary

Fig. 2- Listribuiçao das metastases osseas de acordo com o tumor and the follow-up period, tipo da lesão (lítica, blástica) nos quatro diferentes estadios clínicos.

Fig. 2 - Distribution of bone metastases according to type of lesion (lithic, blastic) in the four different clinical stages. which showed reduction when the clinical staging increased; no correlation was observed between

the other parameters (histological type, number of metastases, kind of lesion, involved bone, and bone localization) and the clinical staging of the breast tumors.

\section{DISCUSSION}

\section{DISCUSSÃO}

O desenvolvimento de metástases ósseas é um fenômeno complexo e altamente seletivo, que envolve o despreendimento das células malignas do sitio primário da lesão, sua sobrevivência enquanto circulam, aderência, invasão vascular e crescimento. $(3,17)$, ou ainda essas células podem invadir o osso por contiguidade

As metástases ósseas estão relacionadas ao aumento da morbidade dos pacientes, como aparecimento de dor, limitação da mobilidade, fraturas patológicas, compressão de estruturas nervosas, hipercalcemia ou supressão da função da medula óssea. A dor frequentemente é o sintoma das metástases ósseas, podendo estar relacionada a diferentes mecanismos como: reabsorção osteoclástica mediada pelas citoquinas, ativação de receptores dolorosos por prostaglandinas, compressão de estruturas nervosas ou instabilidade.3,10

O carcinoma da mama é o tipo de tumor que apresenta a maior
The development of bone metastases is a complex and highly selective phenomenon, involving detachment of the malignant cells from the primary site of the lesion, their survival when in circulation, adhesion, vascular invasion and growth $(3,17)$. These cells can also invade the contiguous bone.

The bone metastases are related to increased morbidity as pain, limitation of movement, pathological fractures, compression of nerve structures, hipercalcemia or supression of the bone marrow function. Pain frequently is the symptom of bone metastases, and it can be related to different mechanisms as: osteoclastic reabsortion mediated by cytokines, activation of the pain receptors by the prostaglandines, compression of the nervous structures or instability. 3,10.

Breast carcinoma is the tumor which presents the higher frequency of bone metastases and there are evidences that well differentiated tumors and those with positive estrogen receptors, present higher indices of bone metastases 16. The histological 
frequencia de metástases ósseas, e existem evidências de que os tumores bem diferenciados e os com receptores de estrógeno positivos, apresentam maiores índices de metástase óssea 16. O tipo histológico de tumor observado em nossa série de pacientes está de acordo com o descrito na grande maioria dos casos de carcinoma da mama, e reconhecidamente um tumor altamente metastatizante (4).

As características do grupo de pacientes que estudamos estão de acordo com a literatura que aborda esse assunto, tendo sido observado um predomínio das lesões metastáticas múltiplas, fato que enfatiza a necessidade da realização da cintilografia óssea durante o seguimento dos pacientes $(7,11)$.O padrão lítico de lesão predominou, refletindo o resultado final da interação das células tumorais e o tecido ósseo $(2,9)$. Essa interação tem sido alvo de muitos estudos, tendo sido descrito vários fatores humorais secretados pelas células do tumor, que são capazes de estimular ou inibir os osteoblastos ou osteoclastos, de modo que a atividade final dessas células determina o padrão lítico ou blástico das lesões (14).

Com relação a freqüência dos ossos afetados, observamos que as costelas constituíram-se no principal sítio de crescimento de metástases, ocorrendo em 22 pacientes (45,8\%) , imediatamente seguido pela coluna vertebral com 20 pacientes $(41,6 \%)$, fêmur com 18 pacientes $(37,5 \%)$ e bacia com 16 pacientes $(33,3 \%)$, que não estão de acordo com os relatos de Lens e Freid (1931)(11), que descreveram 81 casos de carcinoma mamário, nos quais 63\% dos pacientes apresentavam lesões na bacia, 59\% na coluna vertebral , 54\% no fêmur , $40 \%$ nas costelas , 36\% no crânio e $27 \%$ no úmero. Miller e Whitehill (1984)(12) também observaram grande porcentagem de distribuição das lesões na coluna vertebral em 319 pacientes estudados ( $74,6 \%)$ seguida pelo fêmur $(42,6 \%)$ , bacia ( $40,1 \%$ ), úmero $(15,3 \%)$, tíbia ( $2,1 \%$ ) e rádio $(0,3 \%)$. Possivelmente o alto índice de lesões nas costelas, observado em nossos resultado, esteja relacionado ao fato de ter sido considerada a invasão desse osso por contiguidade, tendo sido incluído nessa análise os pacientes pertencentes ao estadio III, que por definição apresentam fixação do tumor na musculatura ou na parede torácica. Apesar da variação encontrada entre estas séries, cabe ressaltar ao leitor que a coluna vertebral permanece como a sede mais frequente de metástases dos tumores malígnos em geral para o esqueleto (6), devido às características da circulação sanguínea nesse local e a existência do plexo venoso de Batson.(1)

A localização preferencialmente metafisária das metástases dos ossos longos, principalmente no fêmur e úmero, devido à presença da medula óssea vermelha, e também dos corpos vertebrais, foi também observado em nossa série de pacientes, estando em concordância com os relatos da literatura $(3,4,13)$.

O tempo de seguimento de nossos pacientes apresentou média de 3anos e 6 meses, semelhante ao observado por Miller \& Whitehill (1984) (12), e foi observado uma diminuição do período de seguimento com o aumento dos graus de estadiamento clínico, tendo sido essa a única correlação observada em nossa série de pacientes estudados. type of tumor observed in our series of patients is in agreement with the one described in the vast majority of breast carcinoma cases, and admittedly a highly metastazing tumor (4).

The characteristics of our group of patients agree with the literature approaching this subject, and a predominance of multiple metastatic lesions was observed; this emphasizes the need to carry out bone scintillography during the follow-up $(7,11)$. The lithic pattern of the lesion predominates, evidencing the final result of the tumor cells interaction and the bone tissue $(2,9)$. This interaction has been subject of several investigations, and several humoral factors secreted by the tumor cells, able to stimulate or inhibit osteoblasts or osteoclasts, have been described; thus, the final activity of these cells establishes the lithic or blastic pattern of the lesions (14). Concerning the frequency of the involved bones, we observed that the ribs were the main site of growth of the metastases, occurring in 22 patients (45.8\%), immediately followed by the spinal column with 20 patients (41.6\%), femur with 18 patients (37.5\%), and hip with 16 patients (33.3\%), in disagreement with the study of Lens and Freid (1931) (11) who described 81 cases of breast carcinoma, in which $63 \%$ of the patients presented hip lesions, $59 \%$ in the spinal column, $54 \%$ in the femur, $40 \%$ in the ribs, $36 \%$ in the cranium, and $27 \%$ in the umerus. Miller and Whitehill (1984)(12) also observed a high percentage of lesion distribution in the spinal column in 319 patients (74.6\%), followed by the femur (42.6\%), hip (40.1\%), umerus (15.3\%), tibia (2.1\%), and radius (0.3\%). Possibly the high index of lesions in the ribs, observed in our study, is related to the invasion by contiguity. Patients belonging to stage III were included in the analysis; by definition, these patients present fixation of the tumor in the musculature or in the thoracic wall. In spite of the variation found in these series, one must emphasize that the spinal column remains the most frequent skeletal site of malignant tumor metastases (6), due to the characteristics of the blood circulation and the existence of the Batson venous plexus. (1)

The preferred metaphyseal localization of the metastases is in the long bones, mainly femur and umerus due to the presence of red bone marrow and in the vertebral body was also observed in our series of patients, and agrees with the literature $(3,4,13)$.

The mean follow-up period of our patients was 3 years and 6 months, according to Miller \& Whitehill (1984) (12) and reduction in the follow-up period was observed when the grades of clinical staging increased; and that was the only correlation observed in our series of patients.

It was not possible to observe correlation between breast carcinoma clinical staging and alteration of bone metastases, so that the tumors which presented more advanced clinical stages did not present higher number of lesions, multiple lesions or preference for a certain localization in the skeleton or specific type of lesion.

The results observed in our investigation do not allow us to establish a correlation between the primary tumoral lesion staging and the metastatic manifestation of that pathology, and this must be considered in the assessment of the patients, in order that low staged lesions are not free from metastases and from possible complications due to bone tissue involvement. 


\section{REFERÊNCIAS}

Não foi possível observar correlação entre o estadiamento clínico do carcinoma mamário e as alterações esqueléticas das metástases ósseas, de modo que os tumores que apresentavam um estadio clínico mais avançado não apresentaram maior número de lesões, lesões múltiplas, ou ainda predileção por uma determina localização esquelética ou tipo específico de lesão.

Os resultados observados em nosso estudo não permitem estabelecer correlação entre o estadiamento da lesão tumoral primária e a manifestação metastática dessa patologia, e esse fato deve ser considerado na avaliação inicial dos pacientes , de modo que lesões com baixo estadiamento não estão isentas de metástases e de suas possíveis complicações devido ao envolvimento do tecido ósseo.
1. BATSON, O. V. : The Function of the vertebral veins and the role in the spread of metastases. Ann Surg 112: 138, 1940.

2. BHARDWAJ, S. \& HOLLAND, J.F. : Chemotherapy of metastatic cancer in bone. Clin Orthop 169:28-37, 1982.

3. BOLAND, P.J. , LANE,J.M. \&, SUNDARESAN, N. : Metastatic disease of the spine. Clin Orthop $169: 95-102,1982$.

4. FISHER,E.R. , GREGORIO, R.M. \&, FISHER,B : The Pathology of invasive breast cancer : A Syllabus derived from the findings of the national surgical adjuvant breast project. Cancer, 36 : 1-85, 1975.

5. Galasko, C.S.B. - Mechanism of bone destruction in the development of skeletal metastases. Nature, 263: 507-508, 1976.

6. GALASKO,C.S.B. : Skeletal Metastases, London, Butterworths, 1986.

7. GALASKO,C.S.B. : Diagnosis of skeletal metastases and assesment of response to treatment. Clin Orthop 312 : 64-75, 1995.

8. JESUS-GARCIA,R. : "Lesões Metastáticas do Osso", in Tumores Ósseos : Uma Abordagem Ortopédica ao Estudo dos Tumores Ósseos, Sao Paulo, 1996. Cap XII , p. 83-90.

9. JOHNSON,B. ; MALLMIN,M.P \&; JOHNSON,J.H. , : Pathoanatomical and Radiographic Findings in Spinal Breast Cancer Metastases. J Spinal Def, 8 : 26-38, 1995.

10. JOHNSTON,A.D. : Pathology of metastatic tumors in bone. Clin Orthop $73: 14,1970$.

11. LENZ,M. \& FREID,J.R. : Metastases to the skeleton, brain and spinal cord from cancer of the breast and the effect of radiotherapy. Ann Surg 93 : 278-2, 1931.

12. MILLER,F. \& WHITEHILL,R. : Carcinoma of the breast metastatic to the skeleton. Clin Orthop 184: 121-127, 1984.

13. MUNDY,G.R. \& YONEDA,T. : Facilitation and suppression of bone metastasis. Clin Orthop 312 : 34-44, 1995.

14. ORR,F.W. ; SANCHEZ-SWEATMAN,O.H. ; KOSTENUIR,P. et al : Tumor-Bone Interactions in Skeletal Metastasis. Clin Orthop 312 : 19-33,1995.

15. PENNA,V. ; TANAKA,M.H. \&; CHUNG,W.T : Tratamento cirúrgico das metastáses ósseas. Rev. Bras. Ortop, 28 : 799-802, 1993.

16. Rubens, R.D. - The nature of metastatic bone disease. In: Rubens, R.D. \& Folgelman, I.- Bone metastasis- diagnosis and treatment. Heidelberg, Springer-Verlag, 1991. p.1-10.

17. SPRINGFIELD, D.S. : Mechanism of metastasis. Clin Orthop 169 : 15- 19,1982 